\title{
10: Islamic education in Myanmar: a case study
}

\author{
Mohammed Mohiyuddin Mohammed Sulaiman
}

\section{Introduction}

'Islam', which literally means 'peace' in Arabic, has been transformed into a faith interpreted loosely by one group and understood conservatively by another, making it seem as if Islam itself is not well comprehended by its followers. Today, it is the faith of 1.2 billion people across the world; Asia is a home for 60 per cent of these adherents, with Muslims forming an absolute majority in 11 countries (Selth 2003:5). Since the terrorist attacks of 11 September 2001, international scholars have become increasingly interested in Islam and in Muslims in South-East Asia, where more than 230 million Muslims live (Mutalib 2005:50). These South-East Asian Muslims originally received Islam from Arab traders. History reveals the Arabs as sea-loving people who voyaged around the Indian Ocean (IIAS 2005), including to South-East Asia.

The arrival of Arabs has had different degrees of impact on different communities in the region. We find, however, that not much research has been done by today's Arabs on the Arab-South-East Asian connection, as they consider South-East Asia a part of the wider 'East', which includes Iran, Central Asia and the Indian subcontinent. Indeed, the term 'South-East Asia' is hardly used in modern Arab literature. For them, anything east of the Middle East and non-Arabic speaking world is considered to be 'Asia' (Abaza 2002).

According to Myanmar and non-Myanmar sources, Islam reached the shores of Myanmar's Arakan (Rakhine State) as early as 712 AD, via oceangoing merchants, and in the form of Sufism. The conversion of local inhabitants to Islam was more by choice than coercion, and the same phenomenon was also the trend for all South-East Asian nations, such as Malaysia and Indonesia (Jilani 1999:63). There were no Muslim attempts to invade Myanmar from outside or to proselytise within (Thiker 1959:338). At the same time, Myanmar, unlike Malaysia or Indonesia, did not present a religious vacuum (Hall 1959:131). What is more, the islands of South-East Asia are easily accessible by sea and presented a very lucrative business and commercial environment (Moshe 1972:105).

\section{Different Myanmar Muslim groups}

Muslims in Myanmar are mostly Sunni, of the Hanafi sect, with a small and ever decreasing number of Shi'ite sect followers. Today, Muslims could constitute 
as much as 13 per cent of the total population, although some experts on Myanmar assume them to constitute about 4 per cent or less, as stated in the official Myanmar census. ${ }^{1}$ Although the census insists that Muslims represent no more than 3.8 per cent of the population (MOFA 2005), the US Central Intelligence Agency (CIA 2005) states that they represent 4 per cent. Myanmar Muslims themselves estimate that they number approximately eight million. ${ }^{2}$ It is not unusual for Muslims residing in non-Muslim countries to feel that the real Muslim census figures are underestimated. Thai Muslims complained about the 1960 Thai national census that recorded 1.5 million Muslims, when their number could have been double that, if not more (see Suthasasna 1983-84).

Muslims in Myanmar can be categorised into four different groups, omitting some significant Muslim minority communities: Pantay (Selth 2003:5-6), the largest group, includes the Rohingya of Rakhine (Arakan) whose members number approximately one million throughout the country; Bamar who converted to Islam in the time of Bamar kings and who call themselves "pure Bamar Muslims'; Indian Muslims born in Myanmar of two Indian Muslim parents; and the Zerbadees, who are the children of mixed marriages between Indian Muslim fathers and Burman mothers (Matthews 2001:5). Each group has very different relationships with the Buddhist majority and with the regime of Myanmar today (Selth 2003:5).

\section{Madrasahs in Myanmar}

Madrasahs (Islamic religious schools) remain the only alternative for educating Myanmar Muslims in Islamic education, since the national school system does not cater for any particular faith or belief with the exception of Buddhism, the faith that more than 70 per cent of people profess. Throughout Myanmar, hundreds of madrasahs are operating, financed by domestic and foreign donations. It is a recent phenomenon that Bamar Muslims have endeavoured to be in touch with their wealthy counterparts in the Arab world to balance the influence of the Indian subcontinent's Islamic ideology.

Madrasah students attend for about 10 or more years, from standards one to 10 , after which they pursue further studies in India, Pakistan or Bangladesh. In some unusual cases, students are sent to the Arabian Peninsula. There is no specific age for enrolling in a madrasah, but students as young as seven years are commonly accepted. Some would choose to spend about two to four years to memorise the 30 chapters of the Holy Qur'an without understanding the Qur'anic texts or their interpretations. Once the student completes the whole of the Qur'an, he would be called 'Hafiz', which would later become a prefix of his name.

He could continue his studies in the field of Mawlawi, in which he learns Fique (Islamic jurisprudence) and Arabic language, its grammar and the interpretation 
of the Qur'an. Although every student would have to go through standards one to 10 to complete a Mawlawi education, a Hafiz could start from standard three, four or five depending on his capability and the teachers' assessment of his capability to cope with his studies. On completion of his studies to standard 10, he would be called 'Mawlawi', which would later become a prefix of his name.

It is a tradition that a man has to be either a Hafiz or Mawlawi to lead the five daily prayers in a mosque. It is normal to find a Hafiz or Mawlawi in almost every Muslim family, as this is regarded as a great honour. As far as the hereafter is concerned, Muslims of Myanmar postulate a reported saying of the Prophet that one who memorises the Holy Qur'an can save 10 of his family members from hell-fire when the Day of Judgment comes. Therefore, one among every 10 family members must be a madrasah graduate to save himself and his family from hell-fire.

Most Myanmar madrasahs are boarding schools exclusively for male students from all over the country. A Muslim boy can enroll in any madrasah irrespective of his ethic background. In some cases, obtaining a recommendation from a reputable Muslim clergyman ('Ulama) or religious person is needed to smooth the enrolment process. At the same time, new madrasahs welcoming young adult female students in Tahfiz (memorising the Qur'an) and Mawlawi courses are being established in Yangon and throughout the Yangon division.

Madrasahs choose to adopt either Burmese or Urdu as their language of instruction and reading Arabic grammar is compulsory, along with reading the Qur'an and the traditions of the Prophet (Hadiths). Graduates of madrasahs can translate Arabic religious texts in either Myanmar or Urdu language, but none of them can communicate fluently in conversational Arabic. In some cases, these Islamic-school graduates are indoctrinated by their respective 'Ulamaand lose a sense of rationality. Neither mathematics nor science subjects are taught in those madrasahs, although attempts are made to introduce English-language courses in some schools.

Some schools actively support Tabligh, the movement that aims to revive Islam among Muslims through a spiritual/personal approach, but they are not interested in converting non-Muslims to Islam. ${ }^{3}$ It is compulsory for a graduate to spend a Chillah (40 days) with Tabligh by travelling to different parts of Myanmar to regenerate Islam. The Tabligh movement postulates that the reason for the fall of Islam was Muslims' failure to uphold the true teaching of Islam in its true form. Today, this noble movement has also become an institution of 'rehabilitation' to which disappointed parents send their mischievous youth with the aim of their sons becoming better Muslims.

The Myanmar administration has never made any serious attempt either to reform madrasahs or to incorporate them into the mainstream of the national education system, as has been the case in Thailand and Malaysia. The absence 
of an authoritative body governing Islamic schools within Myanmar encourages the mushrooming of madrasahs based on certain thoughts and ideas that seem to be Islamic. At times, differences of opinion about certain ideas on Islamic thought become so prevalent among Muslims that sometimes the State has to intervene to defuse tension among various Muslim communities. In one case, the authorities closed one Myanmar-speaking madrasah boarding school outside Yangon when its Muslim supporters were unable to resolve their own internal conflict.

\section{Curriculum of madrasahs in Myanmar}

Most madrasahs' curriculum and teaching systems are similar if not identical to those of the Indian subcontinent. There is no difference of any kind in the teaching textbooks and curriculum until standard four, after which the texts begin to vary. For example, one madrasah might adopt Sharah Wiqayah as a text for Fiqh (Islamic jurisprudence) while another might choose Kanzad Daqa 'iq as its teaching text for the same subject.

There is 95 per cent consistency in the textbooks used for Arabic grammar in all madrasahs. The texts vary again, however, in standard 10, the last year of studies. Some madrasahs will adopt the Mishqad book Sahih Bukhari (the traditions of the holy prophets compiled by Imam Bukhari), Sahih Muslim (the traditions of the holy prophets compiled by Imam Muslim), Abi Dawood (the traditions of the holy prophets compiled by Imam Abu Dawood), Ni Sa'i' (the traditions of the holy prophets compiled by Imam Ni'sa'i'), Tirmizi (the traditions of the holy prophets compiled by Imam Tirmizi) or Ibnu Majah (the traditions of the holy prophets compiled by Imam Ibnu Majah). Some madrasahs teach Tahawi (purification according to Islam) while others use Muwatta' Imam Malik (the traditions of the holy prophets compiled by Imam Malik). The selection of texts will vary according to the instructors' different opinions of the significance and relevance of the questions in the various books.

\section{Languages used in Myanmar madrasahs}

Myanmar Muslims are divided not only over different ethnicity and race, they are divided over different languages used in madrasahs. Indeed, this gap has been significant since the 1930s. In some cases, local communities consider this to be an irreconcilable problem.

Myanmar-speaking Muslims always point to the story of how the first Arab Muslims arrived in Mottama (Martaban) in Lower Myanmar in 1055 AD. An Arab merchant's two sons were rescued by Buddhist monks after their ship capsized near the Mon Kingdom. Today, those two Arab brothers are Byattwi and Byatta, two of the 37 nats (spirits), as known by Burman Buddhists (Mohiyuddin 2005:68). Myanmar Muslims are proud that a Muslim teacher educated the son of King Anawratha, King Saw Lu (Naing 2000:6). They also 
recall the oppressive King Bayinnaung (1551-81 AD), who forced Muslims to convert to Buddhism and forbade the slaughtering of cattle on Islamic holidays. On the other hand, he appointed Muslim translators in his palace and had contacts with King Akhbar of India (Naing 2000:7). King Tar Lun (1629-48) sent Muslim prisoners captured in Pegu, Yangon and Arakan to Central Myanmar, who then settled there.

Bamar Muslims persistently argue that they served under numerous Bamar kings in various capacities, such as teachers, horse riders and soldiers. Some Bamar kings were very fond of them and King Mindon (1853-78) is known to have given religious freedom to his people throughout the country. He built Masjids for Muslims serving his army and residing in his kingdom and appointed Kabul Mawlawi as a religious authority on Islamic matters, allowing him a gold-coloured umbrella (shwe htee), gold bowl (shwe yae tauk phalar) and gold spittoon (shwe htawe khan) (Lay 1971:67). Bamar Muslims also served the last king of Myanmar, King Thibaw (1878-85) (Lay 1971:78).

Bamar Muslims were therefore of the opinion that the Myanmar language should be used in all madrasahs, whereas Indian Muslims, who dominated the management and financed madrasah maintenance, imposed Urdu, the language used in Indian madrasahs.

In fact, an official request was made to teach Myanmar as the major language in all Islamic schools at the Bamar Muslim Education Conference held in Bago (Pegu) in December 1929. Bamar Muslims were offended by the statements made by the then chairman of the Burmese Maulawi Association, Maulana Ismail Ibnu Mohammed Bismillah, who gave the following reasons for Urdu to be maintained as the medium of instruction in all Islamic schools: ${ }^{4}$

- if Urdu was replaced by Myanmar (a language forbidden by Allah), the Muslims of Myanmar would witness a possible stagnation of Islam in the country

- Urdu was the language of Islam in India

- there was a great possibility that Islamic religious knowledge would eventually become extinct if Myanmar replaced Urdu.

As a result, the Bamar Muslim Education Conference, attended by more than 200 delegates and held at Yamethin on 28-29 December 1930, decisively outlined the difficulties faced by the Bamar Muslims and their reasons for wanting to change the language:

- there were no Mawlawi (preachers of Islam) who spoke Myanmar fluently

- many people were unable to understand what the Indian Mawlawis preached

- the way the Mawlawi preached Islam was difficult to follow in practice - so much so that many wanted to convert to other religions 
- Muslims learned no modern languages - that is, Myanmar and English — while they learned Urdu and Arabic from a young age with no comprehensive understanding, making them no use in later years.

The delegates of the conference also proposed that the Bamar (Burman) Muslims should have at least one Mawlawi who could preach in every Myanmar town and it selected young Bamar Muslims to be sponsored to study Islam in Myanmar and English, not in Urdu and Arabic (Lay 1971:172-6). At the national level, in February-March 1937, Bamars endeavoured to make Myanmar the language of the House of Parliament despite protests from European and Indian members (Chakravarti 1971:156). Soon afterwards, Bamar Muslims formed the Burma Muslim Independent Organisation, which adopted the following slogans:

- Bamar race: our race

- Bamar language: our language

- Bamar writings: our writings

- Bamar nation: our nation

- Independence: our religion

- Peace: our discipline

- Capitalism: we don't need

- Mawlawi-ism: we don't need.

Later, Bamar Muslims also formed Bamar (Burman) Muslims Noe Kyar Yae Association (BMNKYA) and Bamar (Burman) Women Muslims Noe Kyar Yae Association (BWMNKYA), with several objectives such as forming a separate identity for Bamar (Burman) Muslims, including a separate register in the Myanmar census.

Today, madrasahs from Yangon, Mawlamyaing, Rakhine and Ayeyarwady - where the majority of non-indigenous and non-Bamar people live - use Urdu extensively in translating Arabic texts, with a few Myanmar words in unavoidable circumstances. It is interesting to recall that the differences about which language to use once caused serious division among the Muslims of Myanmar. Burmese-speaking Myanmar Muslims called for their Urdu-speaking counterparts to demonstrate their undivided loyalty to Myanmar by speaking Burmese and not Urdu, while Urdu-speaking Muslim 'Ulama maintained that Urdu had been the religious language in India and those who spoke Burmese in Islamic matters were 'Muslim bodies with Buddhist souls'.

On the other hand, Pyaw Bwe, Yamethin, Meiktila, Lat Pan, Su Lay Kone, Mandalay, Bone Owe, Shwebo, Kanbalu and many other towns in Upper Burma translate all texts into Myanmar.

It is therefore a common assumption that madrasah graduates from Upper Burma are weak in Urdu and in some cases could not even converse well with their counterparts from Lower Burma. What is more, those madrasah graduates face 
numerous obstacles securing a job as a madrasah teacher in Lower Burma as they are unable to converse in the language that Muslims from Lower Burma consider the 'Islamic [religious] tongue'. In many instances, they have to undergo Urdu-language courses before being appointed as madrasah teachers. On the other hand, madrasah graduates from Lower Burma easily find jobs in madrasahs in Upper Burma, despite their limited Myanmar-language skills.

\section{Ideologies}

Bamar Muslims from Upper Burma do not have Arabic (Muslim) names, unlike their counterparts in Lower Burma. Some of the latter keep their Muslim names for private use and prefer to be addressed by their Myanmar name. Some have been fighting vigorously against the Indian style of Islam by adopting Myanmar names and wearing Myanmar national dress. Most writings of Bamar Muslims focus on Bamar Muslim activities and seek to disassociate their community from non-Bamar Muslims, especially those of Indian descent. Some have gone to extreme lengths to differentiate themselves from Indian Muslims by saying, for example, that there is no difference between Bamar Buddhists and Bamar Muslims, except that Bamar Muslims consume no pork (see Chaye 1986).

Myanmar Muslims from Upper Burma are considered to be more liberal in Islamic thoughts and more accommodating towards different ethnic groups and other faiths. Madrasahs in this area teach students to be more open-minded than those in other areas, and no particular form of dress is considered 'pious'. Madrasahs in Lower Myanmar, however, make it compulsory for their students to dress in Indian style, wearing ' $k u r t a '$ and ' $f e z$ '. All madrasah teachers in Lower Burma wear pious kurta and fez dress.

Any madrasah student or teacher who is not in 'pious' dress is considered to be a 'follower of deviate teachings and the servant of Satan' or anti-Hadith (against the traditions of the Prophet and against accepting the Qur'an as the only revealed source of Islam). Whatever the case is, assumptions about pious dress are meant only for madrasah teachers, not for the general Muslim public.

No text written by any native Myanmar Muslim is used in any madrasah anywhere in the country. The textbooks used are the same as those used in Indian and Pakistani madrasahs, emphasising faith and cultural matters, and leaving out social relationships between Muslims and non-Muslims, politics, psychology, sociology and philosophy. There could be several reasons why Muslims are not welcome in the civil service and state-controlled government institutions, the police or the army, but no madrasah graduate ever thinks of working along with their fellows of the Buddhist faith. At the same time, their qualifications would not allow them to join the civil service domain, as madrasah certificates are not recognised by the regime. 
The concept of jihad is loosely translated as striving for one's best to achieve something that God wishes - not declaring war on non-Muslims over various preconceived notions. Since the September 2001 attacks, Myanmar's authorities have been increasingly concerned about the nature and establishment of madrasahs and the sources of donations and textbooks used in them. During some critical periods, madrasahs in and around Yangon and other places have been instructed to shut down and order their students to return to their respective homes until tranquility is restored in the country. Similar instructions are sometimes given to other schools as well.

The regime imposes restrictions on importing Islamic religious books and other texts from the Indian subcontinent and the Middle East, although its media proclaims that no such restrictions apply. In two cases, books in Urdu sent by Myanmar Muslim students studying in Pakistan were confiscated at the Yangon International Airport ${ }^{6}$ and some bundles of books in Arabic donated by Myanmar Muslims living in Saudi Arabia were stored at the Thai-Myanmar border to be smuggled into Myanmar, if circumstances allowed.

\section{Famous and reputable madrasahs in Myanmar}

Myanmar is home to 759 Islamic schools, according to the official records of the regime. Madrasahs can be placed in two categories: madrasah (school) and jami'ah (university) - although all began as the former before transforming themselves into the latter. Some institutions adopt jami'ah and madrasah in their title, with no apparent explanation. Of all these institutions, some are well known for their academic staff, curriculum and discipline and management (selected madrasahs are listed in Appendix Table 10.1). The story of the establishment of two famous mosques and madrasahs provides an example of the respect with which their founders are still held.

\section{Darul 'Uloom (Tarmwe)}

A Muslim named Ibrahim purchased 17.5 hectares of land in Tarmwe, Yangon, in 1919, of which 19 square metres were allocated on which to build a mosque and the rest became a Muslim cemetery. The headmaster of this madrasah was Maulana Mufi Mahmud Daud Yussuf, who was born in Yangon in 1916. At the age of five, he was entrusted to Maulana Abdul Majid of Shah Jahan Puri, India, to learn Islam. He was later sent to the school of Randeniah to study English. After 1929, he undertook further studies at the school of Mazahirul 'Uloom in Saharan Pur and obtained a Mufti's (expert on Islamic jurisprudence) degree in 1936, the year he married his cousin. He performed the Haj (pilgrimage to Mecca) along with his teacher, Maulana Abdul Rahman. On his return from Mecca, he reluctantly accepted the post of the chairman of Surti Mosque, Yangon. Later, he was assigned to take charge of the Muslim cemetery and became the headmaster of the madrasah until his death. Today, the authorities have closed 
this Muslim cemetery and no new burials are allowed. Maulawi Saleh from Mawlamyaing now heads this madrasah.

\section{Sufia (Botahtaung)}

In 1957-58, Hakim Abdul Aziz set up a Yunani medicine shop in Bohtataung, where he noticed many Muslim children had no knowledge of Islam. Offering them sweets and snacks, he invited them to his medicine house, where he taught them about Islam. During a journey to Bago, he met Adbullah in Waw and Muhammad Saleh, Ahmad, Wali Ahmad, Yusuf Ali, Muhammad Qasim and Muhammad Ali, all of whom headed to Madauk. Here, they met Habibul Rahman, Muhammad Ismail, Muhammed Yakob (big) and Muhammad Yakob (small). They all continued their journey to Nyaunglaybin, where they met the sons of Maulana Abdul Ghafur, Abdul Majid, Abdul Manar and Mu'min. All of them, including Yusuf from Pyun Ta Zar, drove to Yangon and began a small school with 15 students.

\section{Challenges faced by madrasahs in Myanmar}

There seem to be no clear-cut rules and regulations for what a madrasah can do or cannot do in Myanmar. All rules and laws change from time to time. Every Muslim is aware that madrasahs are being closely watched and monitored by the regime, and they behave in the safest way possible. The US Religious Freedom Report and Human Rights Watch have on numerous occasions reported incidents involving the arrest and jailing of some Muslim teachers in state schools, who were teaching students how to read the Qur'an at home.

According to the Myanmar Government's own publications, Islam and its related affairs are controlled, regulated and managed by the Ministry of Religious Affairs of Myanmar, working through five Islamic associations (ibid.:69):

1. Islamic Religious Affairs Council

2. Muslim 'Ulama Association

3. All Myanmar Mawlawi Association

4. All Myanmar Young Muslim Youth

5. Myanmar Muslim League.

The Islamic Religious Affairs Council (IRAC) is the most active Islamic association as it has the blessing of the regime. The Islamic Centre of Myanmar (ICM), set up by the Bamar Muslim U Ba Chit, ${ }^{7}$ acts as a mouthpiece for the IRAC and is active in interfaith dialogue. All its executive members adopt only Myanmar names with the prefix 'Al haj', 8 such as Al Haj U Khin Maung Myint, Al Haj U Tin Nyunt and Haji Ma Daw Hla Shawe. Likewise, none of its committee members, including the daughter of its founder, U Ba Chit, Haji Ma Dr Sandar Chit, has a Muslim (Arabic) name (see ICM 2003). 
The government allows publication of Islamic books and numerous magazines, especially by the ICM, such as Al Irshad (Guidance), Milardun Nabi (The Birth of the Holy Prophet), Al Noor (The Light), Al Balaq (Spreading), Al Hilal (The Crescent), Al Falah (The Success), Al Minar (Minaret), Nurul Islam (The Light of Islam), Lisanul Islam (Language of Islam), Islam Myet Won (The Eye of Islam) and Al Munadi (The Call).

All magazines are informative in nature and highlight local and global news about Islam, including the lives of Muslims in the United States, the winners of the King Feisal Award and feature poems and short stories. Also included are articles about science and Islam, the history of early Bamar Muslims, Muslims in ancient Myanmar, the impact of the Internet on modern youth, the danger of homosexuality and HIV/AIDS. Advertising is accepted from Ahamdiah Muslim Jammat, the organisation termed by the traditional 'Ulama as an 'out-of Islam group'. ${ }^{9}$ The ICM also conducts summer Islamic classes for Bamar Muslims.

Muslims in Myanmar usually believe that they are discriminated against and are treated badly by the regime compared with people of other faiths. Muslims are unhappy that there are only two public holidays for Muslims, Aidil Fitri and 'Idil Adha, of which only one is a gazetted a public holiday, while Buddhists celebrate numerous religious public holidays. At the same time, many Muslims complain that the regime refuses to grant land or waqf (donations of land or property by a Muslim) to set up either a madrasah or a mosque in newly established towns such as Hlaing Thayar and South and North Dagon in Yangon Division.

The lack of an authorised Islamic or neutral news agency in Myanmar has provided fertile ground for all types of Islamic organisations. Ahmadiyah (anti-hadith groups) are gaining more strength among less-educated Muslim urban youths. The traditional 'Ulama's attempt to prohibit quoting any Qur'anic verse or hadith is confronted by a handful of modern youths who spent a few months learning Arabic at Azhar University in Cairo. These youths argue that Islam is for everyone and proclaim that "Ulama must not be allowed to monopolise it'.

At the same time, the traditional 'Ulama have failed to inculcate a sense of Islamic identity in Muslim youths. Many Myanmar Muslims tend to hide their identity and prefer to classify themselves as Buddhist in some situations. Madrasahs will, however, remain in Myanmar into the future as there is no other alternative to the state education system available for Myanmar Muslims. 


\section{Appendix}

\section{Appendix Table 10.1 Famous and reputable madrasahs in Myanmar}

\begin{tabular}{|c|c|}
\hline Name & City/town \\
\hline Darul 'Uloom & Tarmwe, Yangon \\
\hline Sufia & Botahtaung, Yangon \\
\hline Jamiatul 'Ulama & Kanbalu \\
\hline Jamiat Arabia Mazahirul 'Uloom & Pyaw Bwe \\
\hline Madrasah Nu'maniah & Yangon \\
\hline Jamiatul Arabia Islamiah Ta'leemul Qur'an & Thingangyun, Yangon \\
\hline Isha' Atul 'Uloom & Mawlamyaing \\
\hline Imdarul 'Uloom & Kyaikmayaw \\
\hline Madrasah Husseiniah & Maung Gan, Mawlamyaing \\
\hline Madrasah Mahmudiah & Thingangyun, Yangon \\
\hline Madrasah Arabia Hidayatul 'Uloom & Yamethin \\
\hline Madrasah Furqaniah Hafizul Qur'an & Thingangyun, Yangon \\
\hline (Arabic University of) Madinatul 'Uloomul & Yin Daw, Pyaw Bwe \\
\hline (Arabic University of) Madrasah Azziziah & Nan Daw Kone, Meiktila \\
\hline (Arabic University of) Madrasah Khaliliyah & Letpan, Kyaukse \\
\hline (Arabic University of) Miftahul 'Uloom & Bone Owe, Mandalay \\
\hline Madrasah Zammiriah & Kywe Chan Kone Mawlamyaing \\
\hline Madrasah Hakimiah & Laputtar \\
\hline Jami'ah Qasimiah & Ma Kyar Nwe Zin, Mandalay \\
\hline (Arabic University of) Jamia'h Furqaniah & Thathon \\
\hline $\begin{array}{l}\text { (Arabic University of) Jami'ah Arabiah Shamsul } \\
\text { 'Uloom }\end{array}$ & Letpan \\
\hline (Arabic University of) Bisthanul 'Uloom & Pyin Oo Lwin \\
\hline (Arabic University of) Jami'ah Huseiniah & Aung Lan \\
\hline Jami'ah Arabiah Imdadul 'Uloom & Myitkyina \\
\hline Jami'ah Nurul Islam & Kaw Ka Rate, Kayin State \\
\hline Jami'ah Ashraful 'Uloom & Kaw Ka Rate, Kayin State \\
\hline Jami'ah Arabiah Madinatul 'Uloom & Su Lay Gone, Kyaukse \\
\hline (Arabic University of) Muhamadiah & Taung Myint, Mandalay \\
\hline Jami'ah Arabiah Nadwatul 'Uloom & Kan Tar Kone, Shwebo \\
\hline Jai'ah Arabiah Nadwatul 'Uloom & Myint Nge, Mandalay \\
\hline
\end{tabular}


Dictatorship, disorder and decline in Myanmar

\section{Appendix Table 10.2 Number of monasteries, churches, mosques and madrasahs in Myanmar}

\begin{tabular}{|l|c|c|c|c|}
\hline State/division & Monasteries & Churches & Mosques & Madrasahs \\
\hline Kachin State & 655 & 389 & 20 & 23 \\
\hline Kayar State & 147 & 95 & 2 & 5 \\
\hline Karen State & 1014 & 605 & 48 & 69 \\
\hline Chin State & 100 & 898 & 1 & 3 \\
\hline Sagaing Division & 7666 & 148 & 94 & 38 \\
\hline Tanintharyi Division & 1189 & 53 & 76 & 47 \\
\hline Bago Division & 5689 & 146 & 56 & 55 \\
\hline Magwe Division & 5870 & 44 & 29 & 29 \\
\hline Mandalay Division & 8640 & 62 & 200 & 107 \\
\hline Mon State & 2457 & 37 & 94 & 68 \\
\hline Rakhine State & 2716 & 51 & 1238 & 105 \\
\hline Yangon Division & 4109 & 221 & 171 & 111 \\
\hline Shan State & 4695 & 343 & 85 & 35 \\
\hline Ayeyarwady Division & 6240 & 173 & 152 & 64 \\
\hline Total & $\mathbf{5 1} 187$ & $\mathbf{3 2 6 5}$ & $\mathbf{2 2 6 6}$ & $\mathbf{7 5 9}$ \\
\hline
\end{tabular}

Source: Ministry of Defence of Myanmar 1997, Tha Tanar Yang War Htun Say Phoe (Shining the Bright Light of Religion), March, Yangon, pp. 48-73. 


\section{Appendix Table 10.3 Location of mosques within Yangon Division}

\begin{tabular}{|c|c|}
\hline Township & No. \\
\hline Lathar & 1 \\
\hline Lanmadaw & 4 \\
\hline Pabedan & 11 \\
\hline Kyauktada & 8 \\
\hline Botahtaung & 10 \\
\hline Ahlone & 2 \\
\hline Sanchaung & 1 \\
\hline Pazundaung & 2 \\
\hline Dawbon & 2 \\
\hline Insein & 6 \\
\hline Thingangyun & 6 \\
\hline South Dagon & - \\
\hline North Dagon & - \\
\hline Thanlyin & 10 \\
\hline Tone Kwa & 1 \\
\hline Kayin & 3 \\
\hline Kwan Chan Kone & 3 \\
\hline Twantay & 7 \\
\hline Seikgyi Khanaungto & 2 \\
\hline Dala & 6 \\
\hline Than Ta Pin & 1 \\
\hline Mingaladon & 5 \\
\hline Thaketa & 9 \\
\hline North Okkalapa & 2 \\
\hline Shwepyithar & 1 \\
\hline Hlegu & 5 \\
\hline Kaw Mu & 1 \\
\hline Taikgyi & 8 \\
\hline South Okkalapa & 5 \\
\hline Hlaing & 4 \\
\hline Tarmwe & 6 \\
\hline Kyeemyindaing & 1 \\
\hline Mayangone & 3 \\
\hline Mingala Taungnyunt & 18 \\
\hline Hmawbi & 7 \\
\hline Kyauktan & 2 \\
\hline Yankin & 1 \\
\hline Kamaryut & 2 \\
\hline Hlaing Thayar & - \\
\hline Coco Island & - \\
\hline Sate Kan & - \\
\hline Total & 171 \\
\hline
\end{tabular}

Source: Ministry of Defence of Myanmar 1997, Tha Tanar Yang War Htun Say Phoe (Shining the Bright Light of Religion), March, Yangon, pp. 48-73. 


\section{References}

Abaza, Mona 2002, Newsletter, no. 28, August, International Institute of Asian Studies, Netherlands.

Central Intelligence Agency (CIA) 2005, Factbook, viewed 10 November 2005, <http://www.odci.gov/cia/publications/factbook/geos/bm.html>

Chaye, Sayar 1986, Some Things Good to Know About Myself, (In Burmese), A Mar Chit Press, Rangoon.

Chakravarti, Nalini Ranjan 1971, The Indian Minority in Burma: The rise and decline of an immigrant community, Oxford University Press, London.

Hall, D. G. E. 1959, A History of Southeast Asia, London.

International Institute for Asian Studies (IIAS) 2005, University of Amsterdam, Leiden, viewed 5 November 2005, $<$ http://iias.leidenuniv.nl/iiasn/16/regions/sea7.html>

Islamic Center of Myanmar (ICM) 2003, Summer Islamic Course. Volume II, April, Islamic Center of Myanmar, Yangon.

Jilani, A. F. K., 1999, The Rohingyas of Arakan: Their quest for justice, Ahmed Jilani, Dhaka.

Lay, Pathi U Ko Ko 1971, The Union of Myanmar and the Religion of Islam 1404-1945, Yangon.

Matthews, Bruce 2001, Ethnic and Religious Diversity: Myanmar's unfolding nemesis, Institute of South East Asian Studies, Singapore.

Ministry of Foreign Affairs (MOFA) 2005, Government of the Union of Myanmar, viewed 10 November 2005,

<http://www.mofa.gov.mm/aboutmyanmar/religion.html>

Mohammed Mohiyuddin Mohammed Sulaiman, 2005, 'Excluding the Included: Bamar (Burman) Muslims' Quest for Bamar-but-Islamic Identity in Burma', paper presented at 10th anniversary SEASREP (Southeast Asian Studies Regional Exchange Program) conference, Chiang Mai, Thailand, 8-9 December 2005.

Moshe, Yegar 1972, The Crescent in the East: Islam in Asia Major, Curzon Press, Jerusalem.

Mutalib, Hussin 2005, 'Who should speak for Islam in Southeast Asia?', Reader's Digest, August.

Naing, Wa Khae Ma Maung Min 2000, The Union of Myanmar and the Religion of Islam, Part I \& II, Yangon.

Selth, Andrew 2003, Burma Muslims: Terrorists or terrorized?, Strategic and Defence Studies Centre, The Australian National University, Canberra. 


\section{Suthasasna, Arong 1983-84, ‘Occupational distribution of Muslims in Thailand:} problems and prospects', Journal of the Institute of Muslim Minorities Affairs, vol. V.

Thiker, H. 1959, The Union of Burma, London.

\section{Endnotes}

1 Andrew Selth (2003:5) also noted a few who believed that Muslims could constitute 16 per cent, or eight million, of the total population, although most statistics for Myanmar are unreliable and this matter is not an exception. It is said that representatives of faiths other than Buddhism often mistrust the official religious statistics; see Matthews (2001:5).

2 Speech delivered by Maung Ko Ghaffari, 12-15 February 2005, Cheongpyeong, Korea, cited in Lisanul-Islam Magazine, May-June 2005, Yangon, p. 86.

3 The movement was founded by Mawlana Ilyas from India in the early 1940s with the noble intention of bringing the Muslims of India back to Islam. Today, the movement is widely accepted by the people of the Indian subcontinent. It does not publish any books and does not involve itself in any business activities. It shuns politics and refuses to join any activities that bring men to power, which is often misused to subjugate others.

4 Speech by Mawlana Ismail Ibnu Mohammed Bismillah delivered at the Bamar Muslim Education Conference held in Pegu in December 1929.

5 This literally means 'to be quick to hear while asleep, to awake easily, to be on alert, to be vigilant and watchful'. See Judson's Burmese-English Dictionary 1988, p. 586.

6 An interview with one of the students in Pakistan, who requested his name not be revealed for security reasons.

7 Heartiest Acknowledgement to U Ba Chit, published by the Islamic Centre of Myanmar, Yangon.

8 Islamic term referring to someone who has performed the Haj pilgrimage to Saudi Arabia.

9 An advertisement for Ahamdiah Bookstore in Pyi Ar Man magazine, October 1998, Yangon, p. 154. 